\title{
Experimental and numerical analysis of triaxial compression test for a clay soil
}

\author{
Víctor A. Hernández-Hernández ${ }^{1}$, Diego R. Joya-Cárdenas² ${ }^{2}$ Luisa N. Equihua-Anguiano ${ }^{3}$, \\ Julio C. Leal-Vaca ${ }^{4}$, José A. Diosdado-De la Peña ${ }^{5}$, Luis Pérez-Moreno ${ }^{1}$, Noé Saldaña-Robles ${ }^{1}$, \\ and Alberto Saldaña-Robles ${ }^{{ }^{*}}$
}

\begin{abstract}
${ }^{1}$ Universidad de Guanajuato, División de Ciencias de la Vida, Ex Hacienda El Copal km 9, carretera Irapuato-Silao, C.P. 36500, Irapuato, Guanajuato, México. "Corresponding author (alberto.saldana@ugto.mx).

${ }^{2}$ Universidad de Santander, Facultad de Ingenierías, Calle 70 No. 55-210, Bucaramanga, Colombia.

${ }^{3}$ Universidad Michoacana de San Nicolás de Hidalgo, Departamento de Ingeniería Civil, Av. Francisco J. Múgica S/N, Ciudad Universitaria, C.P. 58004, Morelia, Michoacán, México.

${ }^{4}$ Universidad de Guanajuato, División de Ingenierías, Av. Juárez 77, Zona Centro, C.P. 36000, Guanajuato, Guanajuato, México.

${ }^{5}$ Youngstown State University, College of Science, Technology, Engineering and Mathematics, 1 University Plaza, OH 44555, Youngstown, Ohio, USA.
\end{abstract}

Received: 9 January 2021; Accepted: 28 March 2021; doi:10.4067/S0718-58392021000300357

\begin{abstract}
Soil compaction causes negative effects on crop yield and its mechanical response analysis has recently gained relevance for research through numerical methods. In this work, Finite Element Method (FEM) using the Mohr-Coulomb (MC) and Hardening Soil (HS) constitutive models were employed to simulate the mechanical response of a Vertisol agricultural soil. First, an experimental study of the unconsolidated-undrained (UU) triaxial compression test with different moisture contents $(\mathrm{w}=10 \%, 20 \%$ and $34 \%)$ and confining pressures $\left(\sigma_{3}=\sigma_{\mathrm{c}}=0.05 \mathrm{MPa}, 0.10 \mathrm{MPa}\right.$ and $\left.0.15 \mathrm{MPa}\right)$ was carried out, to obtain the shear strength parameters cohesion (c) and friction angle $(\phi)$, as well as the Young's modulus (E) of the soil. The experimental study was conducted through a $3^{2}$ factorial design with three replicates that it was used to evaluate the influence of the $w$ and $\sigma_{\mathrm{c}}$ on $\mathrm{E}$ of the studied soil. Also, an analysis of the behavior of the $\phi$ and $\mathrm{c}$ parameters at each $\mathrm{w}$ was performed. Numerical simulations were done with similar conditions as the experimental tests with respect to loading and boundary conditions. A comparison of the mechanical response between numerical results and physical experiments was carried out. As a result, the MC model allowed to estimate satisfactorily the stress-strain relationship of the soil for w of $10 \%$ and $20 \%$, while HS model exhibited a better approximation for w of $34 \%$ in comparison with the MC model. Finally, the methodology and the adjusted parameters of the agricultural soil obtained in this work, can be used in the study of soil compaction produced by the agricultural machinery.
\end{abstract}

Key words: Finite element method, Hardening soil model, Mohr-Coulomb model, triaxial compression test, Vertisol soil.

\section{INTRODUCTION}

Nowadays, soil compaction is a worldwide problem in modern agriculture, it is responsible for soil degradation of millions of hectares, and it is one of the main reasons that affect plant growth, reducing soil productivity and therefore crop yields (Tracy et al., 2011). The study, prediction and improvement on the understanding of soil compaction through numerical simulation is an alternative to traditional methods. Numerical simulations are acquiring relevance for modeling agricultural soil behavior and its interaction with tillage tools (Ucgul et al., 2018), plants (Dunbabin et al., 2013) and agricultural tires (Zhao and Zang, 2017). Nowadays, numerical tools are an alternative to study soil compaction, root growth and to improve the design of tillage tools and agricultural tires. Finite Element Method (FEM) and Discrete 
Element Method (DEM) are numerical techniques commonly used for modeling soil behavior. According to Ungureanu et al. (2017), FEM is extremely useful to interpret the stress-strain behavior of agricultural soils, and the constitutive soil models most commonly used are the Mohr-Coulomb, Duncan-Chang Hyperbolic, Drucker-Prager and Modified CamClay (David et al., 2015). On the other way, the laboratory test used to determine the mechanical properties of soils is usually the triaxial compression test (Lee et al., 2012).

In the literature, several researchers have studied the soil mechanical response using the FEM. Herrera et al. (2008a) studied the mechanical behavior of an Oxisol by means Mohr-Coulomb and Extended Drucker-Prager models and numerical simulations. As a result, the Extended Drucker-Prager model showed more accuracy to simulate the mechanical response of the Oxisol in comparison with experimental results obtained using the triaxial compression tests. Herrera et al. (2010) simulated the stress-strain relationship of three Cuban clay soils using FEM and studied the accuracy of the Duncan-Chan model in comparison with experimental data obtained by the triaxial compression test. The results showed that the Duncan-Chan model accurately predicted the soil behavior when a plastic failure is expected. Mendoza et al. (2014) studied the mechanical behavior of the Brasilia's clay by triaxial tests and numerical simulations using three material models for the soil. Here, the subloading Cam Clay model presented a less rigid transition of the stressstrain relationship similar to the experimental results, while the hypoplasticity with structure model better represented the cementing effect in the drained triaxial tests. Other authors used DEM to simulate and replicate the triaxial compression test and study the behavior of mainly granular materials (Duan et al., 2017; Nguyen et al., 2018).

In this context, the aims of this work were to: (1) realize an experimental study to obtain the shear strength properties cohesion (c) and friction angle $(\phi)$ and elastic modulus (E) of a soil widely used in agriculture of central Mexico, with different moisture contents $(\mathrm{w})$ and confining pressures $\left(\sigma_{3}=\sigma_{\mathrm{c}}\right)$, using unconsolidated-undrained (UU) triaxial compression test; (2) study the influence of the moisture content with three different confining pressures on its mechanical properties, such as the Young's modulus (E), c and $\phi$; (3) develop a Finite Element (FE) model of the triaxial compression test, using the Mohr-Coulomb and the Hardening soil constitutive models to simulate the soil behavior; and (4) compare the stress-strain relationship obtained by simulation and the experimental results. The mechanical properties of the soil obtained will be used in future research for the study of the effect of the agricultural soil compaction.

\section{MATERIALS AND METHODS}

\section{Experimental tests to determine mechanical properties of the soil}

This research work was carried out using an agricultural soil of the experimental field of the University of Guanajuato $\left(20^{\circ} 44^{\prime} 43^{\prime \prime} \mathrm{N}, 101^{\circ} 19^{\prime} 40^{\prime \prime} \mathrm{W} ; 1730\right.$ m a.s.l.), in the southwestern part of the State of Guanajuato in central Mexico. The agricultural soil of the experimental region was classified as a Vertisol (Typic Haplustert) according to the USDA Soil Taxonomy (Soil Survey Staff, 2014). This soil is considered as one of the most productive in the country and it is the agricultural soil with the highest presence in the State of Guanajuato (Torres Guerrero et al., 2016).

A soil sample was collected to determine the mechanical properties in a soil layer ranging from 0 to $30 \mathrm{~cm}$ depth. Farming operations are commonly carried out at this soil depth. Besides, the classification of soil layer (USDA Taxonomy) was carried out using the Unified Soil Classification System (USCS) by the ASTM D2487 standard (ASTM, 2017). For this, a combined granulometric test was performed according to the ASTM D422-63 standard and Atterberg limits established the ASTM D4318 standard. Also, a linear shrinkage analysis in accordance with the Proctor Standard-ASTM D698 and organic matter content under the NMX-AA-21 Standard (SEMARNAT, 2000) was carried out. Table 1 shows the basic properties of the collected soil layer.

In a first step, a Proctor Compaction Test according to Proctor Standard-ASTM D698 was performed to obtain moisture contents $(\mathrm{w})$ that can affect dry volumetric weight $\left(\gamma_{\mathrm{d}}\right)$ of the agricultural soil studied (Figure 1). Three w values of $10 \%, 20 \%$ and $34 \%$ were taking from the dry side of the compaction curve, because these are values that can cause an unfavorable effect in the soil by the tires of the agricultural machinery. The last value is the most unsuitable w because according to the compaction theory, this water content develops the minimal void relationship (e) in the soil and therefore the maximum compaction. For the case of agricultural soils, this value affects the growth of the plants. 
Table 1. Summary of properties of soil sample.

\begin{tabular}{lc}
\hline Properties & Value \\
\hline Gravel, \% & 0.0 \\
Sand, \% & 12.2 \\
Silt, \% & 25.0 \\
Clay, \% & 62.8 \\
Liquid limit, \% & 75.6 \\
Liquid plastic, \% & 38.6 \\
Plasticity index, \% & 37.0 \\
USCS & MH \\
Linear shrinkage, \% & 11.8 \\
Natural moisture content, \% & 6.7 \\
Natural dry density, $\mathrm{g} \mathrm{cm}^{-3}$ & 1.8 \\
Maximum dry density, $\mathrm{g} \mathrm{cm}^{-3}$ & 1.3 \\
Optimum moisture content, $\%$ & 34.0 \\
Compaction degree, $\%$ & 140.0 \\
Organic matter content, \% & 5.7 \\
\hline USCS: Unif Soil Cle
\end{tabular}

USCS: Unified Soil Classification System; MH: high plasticity silt.

Figure 1. Compaction curve for the studied soil.

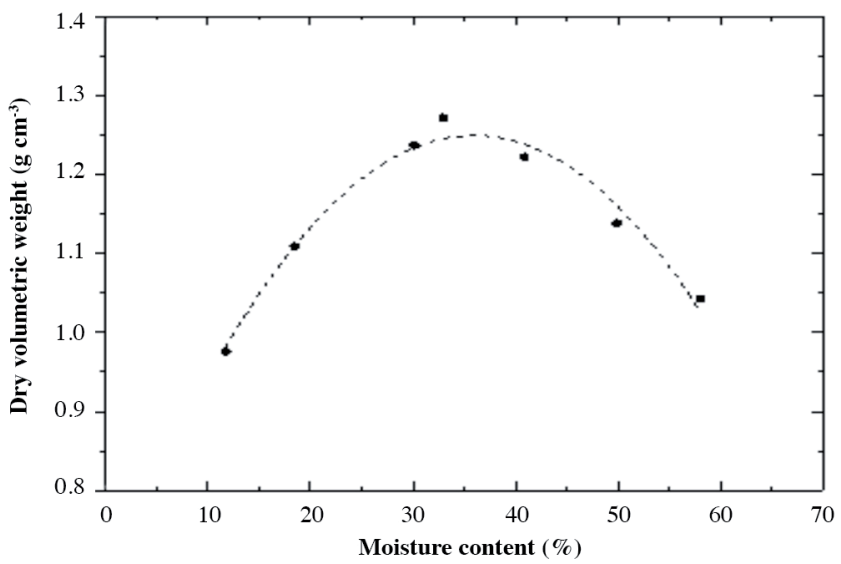

Then, an experimental study of the unconsolidated-undrained (UU) triaxial compression test was carried out, using reconstituted triaxial samples, to obtain the stress-strain behavior of the soil. This study was performed in the Soil Mechanics Laboratory of the University of Guanajuato. The experiment was conducted using three soil moisture contents: low (10\%), medium (20\%) and high (34\%); for each moisture level considered, three confining pressures $(0.05,0.10$ and $0.15 \mathrm{MPa}$ ) were tested and three replicates for each combination of $\mathrm{w}$ and the confining pressure. For this, an experimental study of 27 triaxial compression trials was performed by the ASTM D2850 standard, Standard Test Method for UU Triaxial Compression Test on cohesive soils. For the experiments, w was measured using an oven-drying at $110{ }^{\circ} \mathrm{C}$ for 24 $\mathrm{h}$ as recommended by ASTM D2216. The unconsolidated-undrained triaxial compression test was carried out using the Digital Tritest 50 equipment (ELE International, Bedfordshire, UK; Figure 2A). In each test, a cylindrical soil specimen was prepared with a specific $\mathrm{w}$ and a relationship height/diameter of 2:1 (76 $\mathrm{mm}$ height and $38 \mathrm{~mm}$ diameter) (Figure 2B). A latex membrane was used to seal the cylindrical soil specimen, which was positioned in the triaxial pressure chamber. The soil specimen was subjected to a controlled confining pressure $\left(\sigma_{3}=\sigma_{c}\right)$ using water in the chamber. Later, an axial load $\left(\Delta \sigma_{d}=\sigma_{1}-\sigma_{3}\right)$ is applied up to the point where the sample fails; during the test, no drainage of the sample was allowed and the axial load remains at a constant speed of $1.17 \mathrm{~mm} \mathrm{~s}^{-1}$ (Figure 2C). In a second step, Young's modulus (E), friction angle $(\phi)$ and cohesion (c) shear properties of the soil for the three $\mathrm{w}$ and their replicates were obtained. Young's modulus was obtained as the initial slope of the stress-strain relationship (secant modulus). The graphic method of the Mohr circles was used to obtain $\phi$ and c, using three circles corresponding to the confining pressures for each moisture level. Finally, a $3^{2}$ factorial design (FD) was used to investigate the effect of $w$ and the confining pressure on the E parameter (Table 2). Likewise, an analysis of the behavior of $\phi$ and $\mathrm{c}$ shear parameters depending on the w was carried out. 
Figure 2. Digital tritest equipment (A), soil specimen (B) and triaxial test in progress (C).

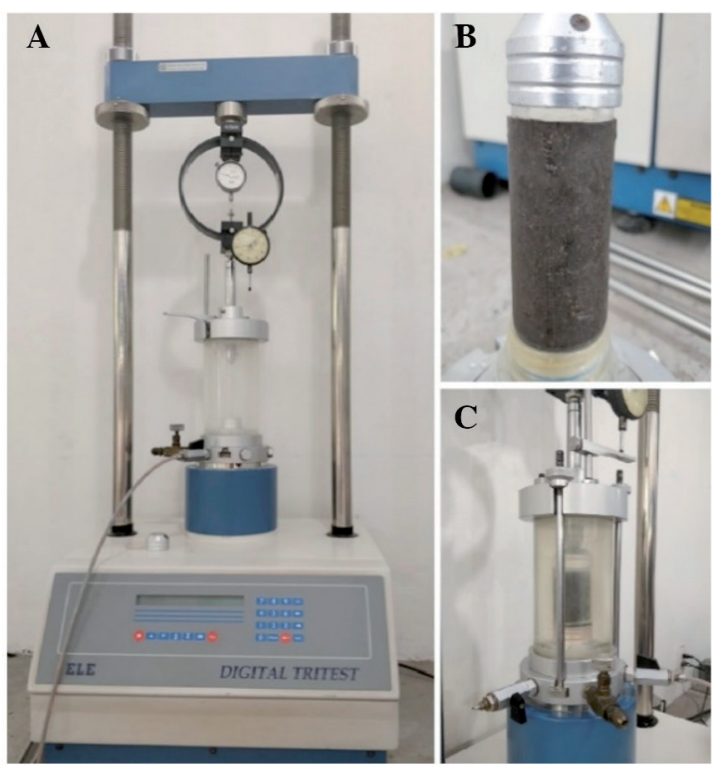

Table 2. Factors and levels for $3^{2}$ factorial design.

\begin{tabular}{lrrr}
\hline & \multicolumn{3}{c}{ Level } \\
\cline { 2 - 4 } Factor & \multicolumn{1}{c}{-1} & \multicolumn{1}{c}{0} & \multicolumn{1}{c}{1} \\
\hline Moisture $(\mathrm{w}), \%$ & 10.00 & 20.00 & 34.00 \\
Confining pressure $\left(\sigma_{\mathrm{c}}\right), \mathrm{MPa}$ & 0.05 & 0.10 & 0.15 \\
\hline
\end{tabular}

Finite element model of the unconsolidated-undrained triaxial compression test

A numerical model of the UU triaxial compression test for the Vertisol was developed using FEM. The soil specimen was modeled by two soil constitutive models, Mohr-Coulomb (MC) and Hardening Soil (HS) models (Bentley, 2020). Experimental parameters in combination with the soil properties obtained from the literature were adjusted and used as the input data in the numerical simulations.

The MC model is considered as a perfect elastoplastic model with a first-order approximation to the non-linear behavior of the soil and this model can simulate the behavior of fine or granular soils. To approximate the soil behavior by the MC Model, five input parameters are required: E, $\phi$, c, Poisson's ratio (v), and dilatancy angle $(\psi)$. The mechanical properties $\mathrm{E}, \phi$ and $\mathrm{c}$ were determined for the three moisture levels in the previous section. The $\mathrm{v}$ value for unsaturated clay soil must be less than 0.35 according to Nieto Leal et al. (2009). Unconsolidated clays showed a very low dilation, therefore, $\psi$ can be considered as zero (Jawad et al., 2020). From these initial values, the parameters were adjusted for the simulations.

The HS model is considered an elastoplastic hyperbolic model, based on classical plasticity theory. This is a secondorder model suitable to simulate the behavior of clays, sands, silts and gravel (Teo and Wong, 2012; Bentley, 2020). To approximate the soil behavior by the HS model, the following parameters were used: (a) MC failure parameters $\phi, c$ and $\psi$; (b) the basic parameters for the soil stiffness, which are the reference secant stiffness ( $\mathrm{E}^{\mathrm{ref}}{ }_{50}$ ), reference tangent stiffness $\left(E^{\text {ref }}{ }_{\text {oed }}\right)$, reference unloading-reloading stiffness $\left(E_{\text {ur }}^{\text {ref }}\right)$ and power exponent of stiffness-stress level correlation $(m)$; and (c) the advanced parameters, these are: the unloading-reloading Poisson's ratio $\left(\mathrm{v}_{\mathrm{ur}}\right)$, reference stiffness stress $\left(\mathrm{p}^{\text {ref }}\right)$, side pressure coefficient $\left(\mathrm{K}_{0}\right)$ and failure ratio $\left(\mathrm{R}_{\mathrm{f}}\right)$.

Some assumptions for HS model parameters considered in this work are: $\mathrm{m}=1.0$ for a soft clay (Wu and Tung, 2020), $\mathrm{v}_{\mathrm{ur}}=0.2, \mathrm{~K}_{0}=1-\sin \phi$ and $\mathrm{R}_{\mathrm{f}}=0.9$ (default settings suggested by PLAXIS software; Bentley Systems, Exton, Pennsylvania, USA). The stiffness modules ( $\mathrm{E}^{\text {ref }}{ }_{50}, \mathrm{E}^{\text {ref }}{ }_{\text {ur }}$ and $\mathrm{E}^{\text {ref }}$ oed $)$ were calibrated, taking as initial values: $\mathrm{E}^{\text {ref }}{ }_{50}$ is the secant stiffness at $50 \%$ of the maximum deviatoric stress, at a pressure equal to the reference stress (default value is $\mathrm{p}^{\text {ref }}=100 \mathrm{kN} \cdot \mathrm{m}^{-2}$ ), $\mathrm{E}^{\text {ref }}{ }_{\text {oed }} \approx \mathrm{E}^{\text {ref }}{ }_{50}$ and $\mathrm{E}^{\text {ref }}{ }_{\text {ur }} \approx 3 \mathrm{E}^{\text {ref }}{ }_{50}$ according to PLAXIS. The main difference between MC and HS is the stiffness approach, the second model is described more accurately by employing three input stiffness $\left(\mathrm{E}^{\text {ref }}{ }_{50}, \mathrm{E}^{\text {ref }}{ }_{\text {ur }}\right.$ and $\left.\mathrm{E}^{\text {ref }}{ }_{\text {oed }}\right)$. 
A general procedure of the numerical simulation of the triaxial test is shown in Figure 3 to facilitate the understanding of the methodology steps order.

Figure 3. Flow chart of the numerical simulation of the triaxial test.

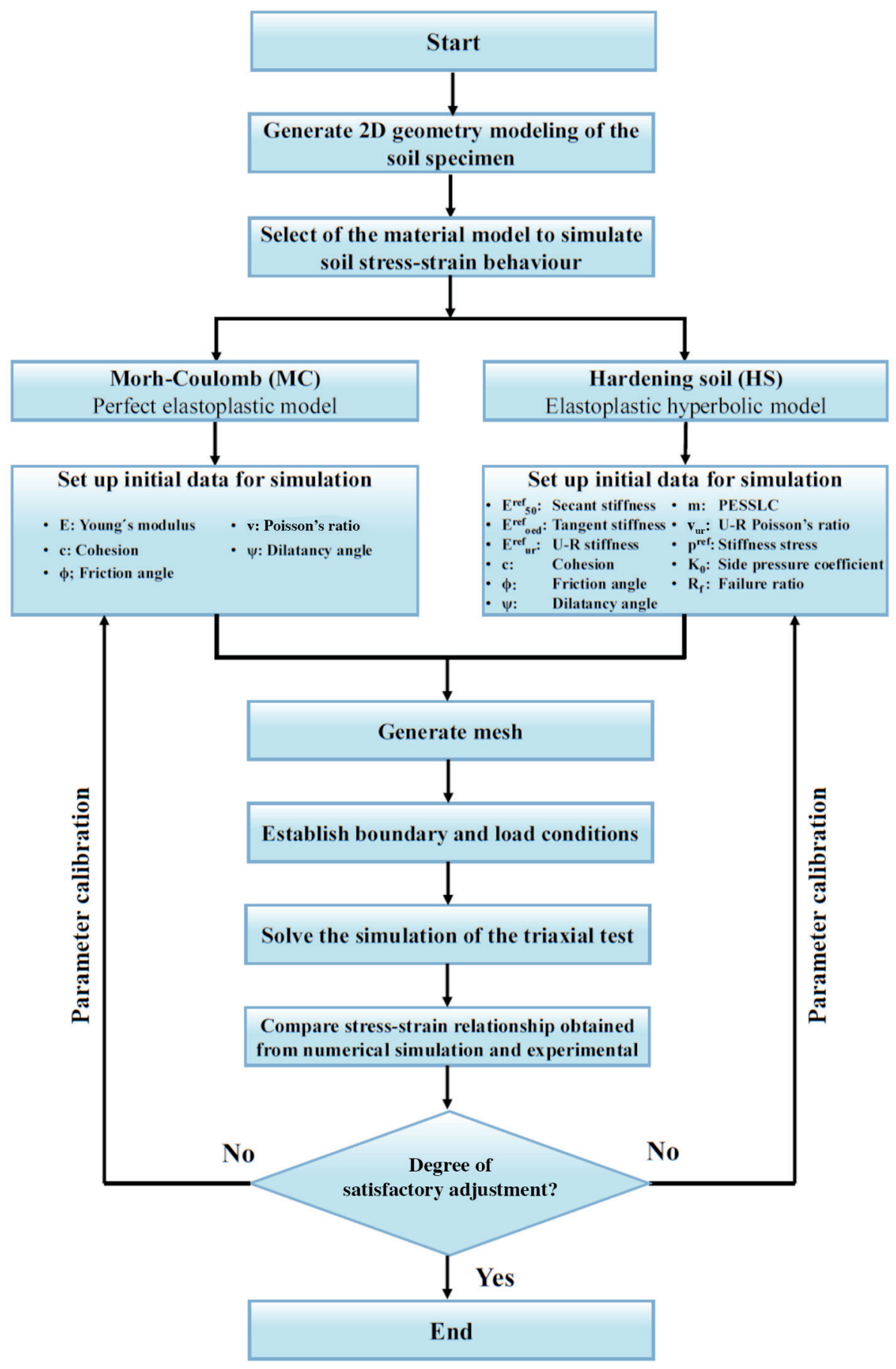

U-R: Unloading-reloading stiffness.

PESSLC: Power exponent of stiffness-stress level correlation. 
First step, the soil specimen geometry was built in the structure module in the Finite Element Software PLAXIS 2D. To simplify the triaxial test model, the soil sample was modeled with an axisymmetric geometry of $1.0 \mathrm{~m} \times 1.0 \mathrm{~m}$, which represents a quarter of the soil sample (Figure 4). Although the model dimensions are not realistic in comparison to the experimental sample, the dimensions of the model do not influence the results because the soil weight was not considered, and if the real dimension is considered the model can be unstable or presents numerical mistakes due to the proximities in the borders. Second step is the material model (MC or HS) selection and the third step is the initial setup of data according to the material model. Fourth step is to generate the mesh. To model the stresses and deformations in the soil, a 15-noded triangular element was employed to mesh the soil sample, which involves a fourth-order interpolation for displacements and the numerical integration provides 12 stress points. A medium global coarseness was selected, which generated in the finite element model 242 elements and 2041 nodes. Fifth step, establishing boundary and load conditions. As boundary conditions, the left boundary (line from P1 to P2) and the bottom boundary (line from P2 to P3) of the model are axes of symmetry (Figure 4), in these axes of symmetry, the displacements perpendicular to the axes were fixed imposing cero displacement $\left(\mathrm{U}_{\mathrm{x}}=0\right.$ for line P1P2 and $\mathrm{U}_{\mathrm{y}}=0$ for the line P2P3). While the displacements along the axes of symmetry were maintained free to allow a smooth movement along the boundaries $\left(U_{y}=\right.$ free for line P1P2 and $U_{x}=$ free for line $\mathrm{P} 2 \mathrm{P} 3)$. As load conditions, the soil specimen was subjected to a distributed load, the confining pressure $\left(\sigma_{3}=\sigma_{c}\right)$, which was applied to the top (line P1P4) and the right (line P4P3) boundaries at negative directions of the axes. Thus, a second distributed axial load $\left(\sigma_{1}-\sigma_{3}\right)$ was applied to the top boundary at the negative direction of the vertical y-axis until failure (Figure 4), to simulate the deviator stress increment. These conditions, confining pressure $\left(\sigma_{c}\right)$ and deviatoric stress (axial load) $\left(\Delta \sigma_{\mathrm{d}}\right)$, represent the conditions implemented during the experimental tests. Sixth step is solving the finite element model. In seventh step, the numerical stress-strain relationships were compared with the experimental result to verify their fit, if the degree of adjustment was not satisfactory, the parameters set are recalibrated through curves fitting. A total of three scenarios were evaluated for each soil model (MC and HS), each scenario using different setup parameters to obtain a numerical stress-strain curve.

\section{RESULTS AND DISCUSSION}

\section{Experimental tests to determine mechanical properties of the soil}

Figure 5A shows the stress-strain curves for the three moisture contents (w) at $0.05 \mathrm{MPa}$ confining pressure $\left(\sigma_{3}=\sigma_{\mathrm{c}}\right)$. The highest deviatoric stress $\left(\Delta \sigma_{\mathrm{d}}=\sigma_{1}-\sigma_{3}\right)$ was obtained for the lowest $\mathrm{w}(10 \%)$, which presents a brittle failure with a breakpoint and shear plane well-defined (Figure 5A, black curve), after the maximum deviatoric stress, it decreases rapidly. For the medium $\mathrm{w}(20 \%)$, a similar behavior was obtained, however, a decrease in the maximum $\Delta \sigma_{\mathrm{d}}$ is presented (Figure $5 \mathrm{~A}$, red curve). The lowest $\Delta \sigma_{\mathrm{d}}$ was achieved with the highest $\mathrm{w}(34 \%)$. In this case, the soil begins to flow plastically without defining a failure point (Figure 4A, blue curve), and does not presented shear failure planes, but barrelling failure is observed in the soil test specimen. These kinds of behavior are characteristic of clayey and granular soils in triaxial compression test, as reported by Herrera et al. (2008a), Mánica et al. (2018) and Ren et al. (2018). Similar behavior of the stress-strain curves for the other confining pressures $\left(\sigma_{\mathrm{c}}=\sigma_{3}=0.10\right.$ and $\left.0.15 \mathrm{MPa}\right)$ at each $\mathrm{w}$ was obtained, but an increase in the maximum $\Delta \sigma_{\mathrm{d}}$ is observed as the confining pressure increases from $\sigma_{\mathrm{c}}=\sigma_{3}=0.05$ to $0.15 \mathrm{MPa}$ (Figure 5B).

Figure 4. Simulation detail, simplified geometry of the finite element model of the triaxial test (A) and loading steps applied to the model (B).
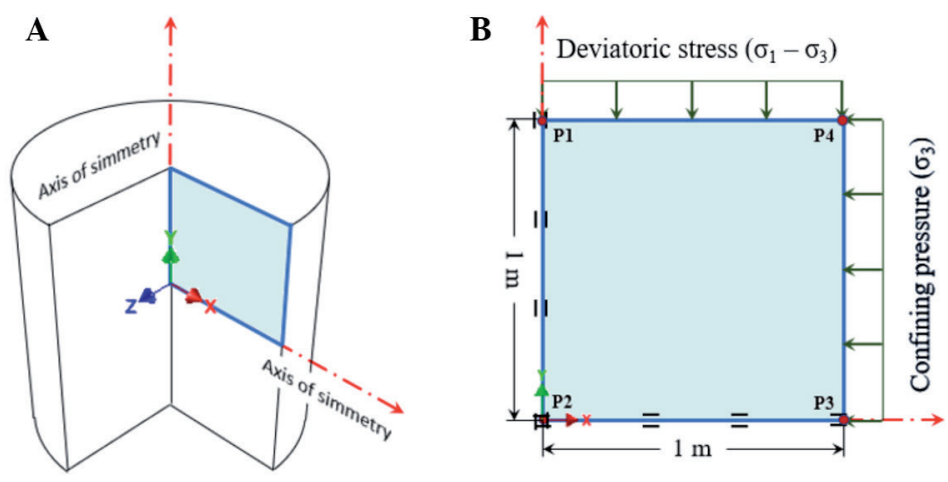
Figure 5. Stress-strain curves for different moisture contents (w) at $0.05 \mathrm{MPa}$ of confining pressure $\left(\sigma_{3}=\sigma_{\mathrm{c}}\right)(\mathrm{A})$ and different confining pressure at $\mathrm{w}=10 \%(\mathrm{~B})$.
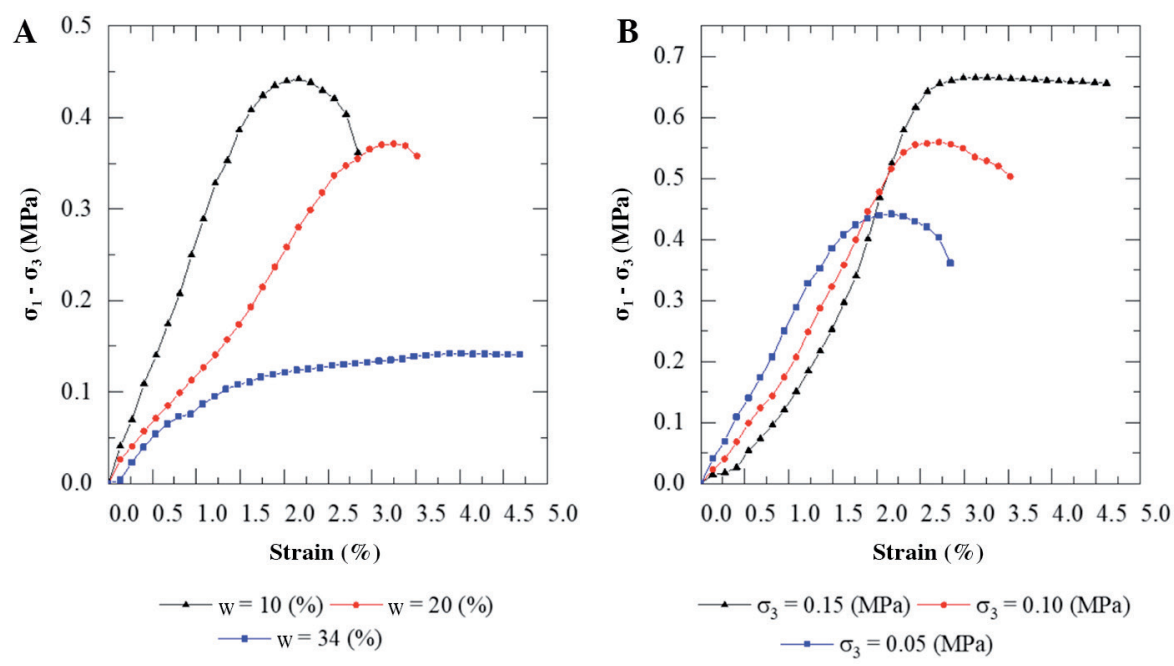

Table 3 shows E values obtained from the stress-strain relationships of the 27 samples tested in UU conditions using the triaxial apparatus. Likewise, it presents the shear strength values $\phi$ and $\mathrm{c}$, for each $\mathrm{w}$ and the three confining pressures $\left(\sigma_{\mathrm{c}}=\sigma_{3}\right)$ and according to the graphic method of the Mohr circles.

Table 3. Mechanical properties Young's modulus, friction angle and cohesion obtained from the unconsolidated-undrained (UU) triaxial compression tests.

\begin{tabular}{|c|c|c|c|c|c|}
\hline \multirow[b]{2}{*}{$\begin{array}{l}\text { Moisture } \\
\text { (w) }\end{array}$} & \multirow[b]{2}{*}{$\begin{array}{l}\text { Replicate } \\
\text { number }\end{array}$} & \multirow[b]{2}{*}{$\begin{array}{c}\text { Confining } \\
\text { pressure }\left(\sigma_{3}\right)\end{array}$} & \multicolumn{3}{|c|}{ Parameters } \\
\hline & & & $\begin{array}{c}\text { Young's } \\
\text { modulus (E) }\end{array}$ & $\begin{array}{c}\text { Friction } \\
\text { angle }(\phi)\end{array}$ & $\begin{array}{l}\text { Cohesion } \\
\text { (c) }\end{array}$ \\
\hline$\%$ & & -1 & 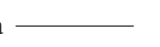 & $\mathrm{MPa}$ & o \\
\hline \multirow[t]{9}{*}{10} & 1 & 0.05 & 24.17 & 0.1031 & 30.39 \\
\hline & & 0.10 & 23.61 & & \\
\hline & & 0.15 & 22.09 & & \\
\hline & 2 & 0.05 & 21.82 & 0.1009 & 29.34 \\
\hline & & 0.10 & 19.86 & & \\
\hline & & 0.15 & 21.71 & & \\
\hline & 3 & 0.05 & 20.18 & 0.1101 & 30.17 \\
\hline & & 0.10 & 23.32 & & \\
\hline & & 0.15 & 19.43 & & \\
\hline \multirow[t]{9}{*}{20} & 1 & 0.05 & 9.27 & 0.1201 & 15.43 \\
\hline & & 0.10 & 11.15 & & \\
\hline & & 0.15 & 12.31 & & \\
\hline & 2 & 0.05 & 11.04 & 0.0986 & 14.38 \\
\hline & & 0.10 & 12.42 & & \\
\hline & & 0.15 & 11.43 & & \\
\hline & 3 & 0.05 & 10.09 & 0.1179 & 14.98 \\
\hline & & 0.10 & 9.15 & & \\
\hline & & 0.15 & 10.09 & & \\
\hline \multirow[t]{9}{*}{34} & 1 & 0.05 & 6.29 & 0.0536 & 2.44 \\
\hline & & 0.10 & 7.56 & & \\
\hline & & 0.15 & 7.38 & & \\
\hline & 2 & 0.05 & 6.44 & 0.0595 & 2.02 \\
\hline & & 0.10 & 7.10 & & \\
\hline & & 0.15 & 8.78 & & \\
\hline & 3 & 0.05 & 6.62 & 0.0600 & 2.20 \\
\hline & & 0.10 & 8.86 & & \\
\hline & & 0.15 & 7.28 & & \\
\hline
\end{tabular}


The ANOVA for $\mathrm{E}$ was conducted and F-values, p-values and the percentage contribution of each source are given in Table 4. Results indicated that $\mathrm{w}$ factor produces a significant effect on $\mathrm{E}$ with a $95.0 \%$ confidence level. This factor is affecting $\mathrm{E}$ with a considerable percentage contribution $(\mathrm{P})$ of $96.1 \%$. On the other hand, the confining pressure factor $\left(\sigma_{\mathrm{c}}=\sigma_{3}\right)$ and the interaction of both factors are not significantly affecting $\mathrm{E}$ with a minimum percentage contribution of $0.3 \%$ and $0.5 \%$, respectively.

Figure 6A presents the values of $\mathrm{E}$ for different $\mathrm{w}$ and confining pressures $\left(\sigma_{\mathrm{c}}=\sigma_{3}\right)$, which shows that $\mathrm{E}$ decreases as $\mathrm{w}$ increases, while the confining pressure values used in this work does not affect $\mathrm{E}$, this corroborates the ANOVA results and agrees with the literature (Huang et al., 2020).

The behavior of the $\phi$ parameter for the three $\mathrm{w}$ is shown in Figure 6B. It can be noted that $\phi$ decreases when $\mathrm{w}$ increases, since the latter produces that friction between particles decreases, similar behavior is reported in clay soils by Leong et al. (2013).

Table 4. ANOVA results for Young's modulus (E).

\begin{tabular}{|c|c|c|c|c|c|c|}
\hline Source & Sum of squares & df & Mean square & F-value & p-value & $\mathrm{P}(\%)$ \\
\hline A-Moisture content (w) & 1024.30 & 2 & 512.15 & 275.01 & $<0.0001$ & 96.1 \\
\hline B-Confining pressure $\left(\sigma_{\mathrm{c}}=\sigma_{3}\right)$ & 2.89 & 2 & 1.44 & 0.7749 & 0.4755 & 0.3 \\
\hline $\mathrm{AB}$ & 5.36 & 4 & 1.34 & 0.7194 & 0.5898 & 0.5 \\
\hline Error & 33.52 & 18 & 1.86 & & & 3.1 \\
\hline Total & 1066.07 & 26 & & & & 100.0 \\
\hline
\end{tabular}

Figure 6. Behavior of the soil parameters: (A) Young's modulus under different confining pressure $\left(\sigma_{\mathfrak{c}}=\sigma_{3}\right)$ and moisture contents, (B) friction angle under different moisture contents and $(C)$ cohesion for different moisture contents.
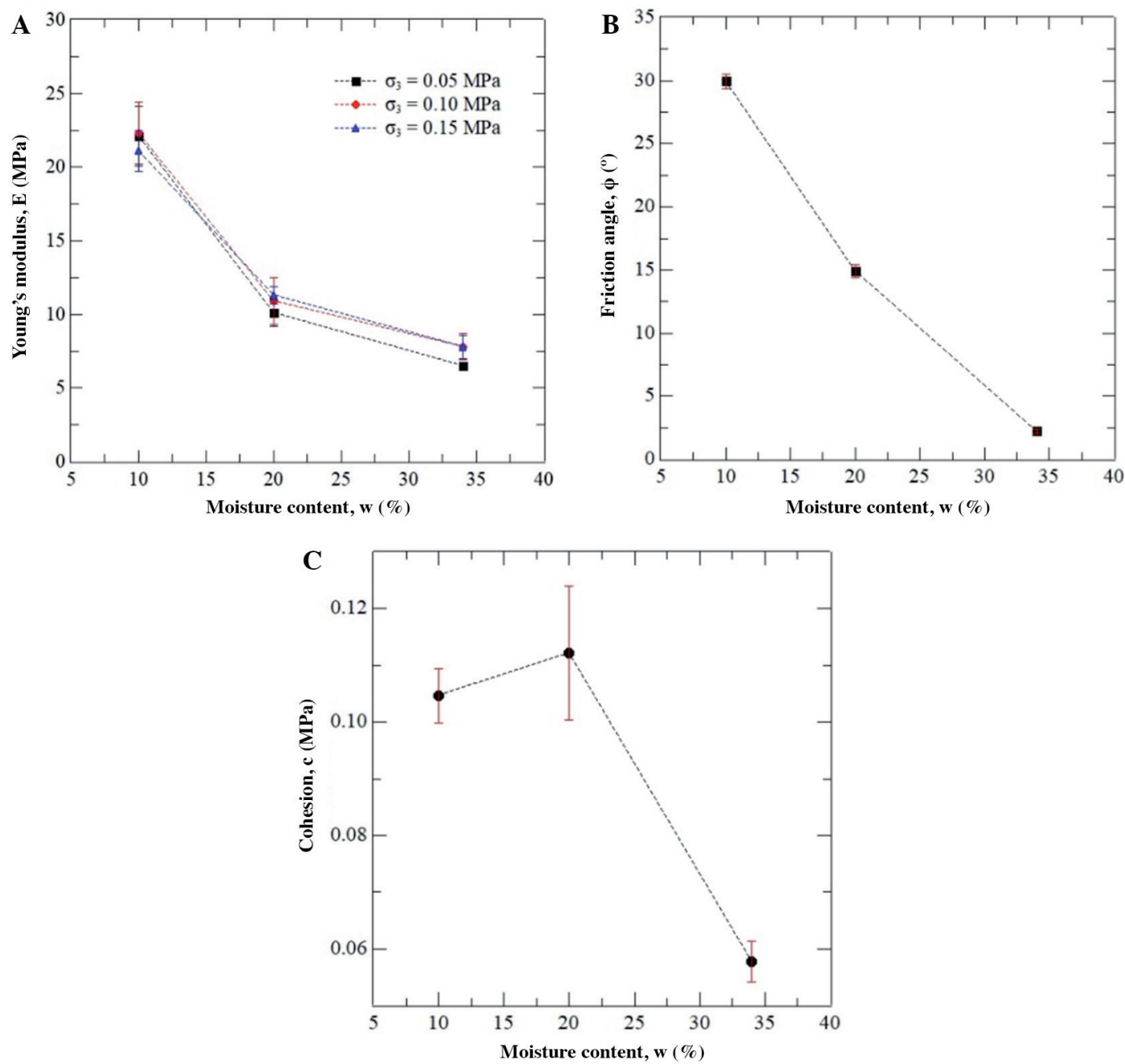
Figure $6 \mathrm{C}$ shows the $\mathrm{c}$ parameter for the three $\mathrm{w}$, it is observed that this property increases to a maximum value, when soil w increases from $10 \%$ to $20 \%$, this effect is attributable to the formation of meniscus. Once the soil begins to saturate from $20 \%$ to $34 \% \mathrm{w}$, capillary softening occurs and the c value decreases considerably (Leal et al., 2012). Other authors reach similar results, for instance Hossne et al. (2011) stated that the increase in w produces that $\mathrm{c}$ tends to be negligible.

\section{Finite element model of the UU triaxial compression test}

Tables 5 and 6 show the adjusted parameters obtained from the experimental study and the literature, which were used as the input data in the numerical simulations to approximate the stress-strain relationship for both, the Morh-Coulomb (MC) and Hardening soil (HS) constitutive models. In the same way, the obtained stress-strain numerical curves were compared with those obtained from the laboratory experiments.

The numerical stress-strain curves and those obtained experimentally are shown in Figure 7. These numerical stressstrain curves were obtained for a confining pressure of $\sigma_{\mathrm{c}}=\sigma_{3}=0.15 \mathrm{MPa}$ with $\mathrm{w}=10 \%, 20 \%$ and $34 \%$. From the numerical simulations, the maximum $\Delta \sigma_{\mathrm{d}}\left(\sigma_{1}-\sigma_{3}\right)$ was obtained with a maximum absolute percentage error of $6.4 \%$ and $4.8 \%$ for the $\mathrm{MC}$ and the HS constitutive models, respectively.

In Figure 7A, for the low w (10\%), the experimental curve presents a hypoplastic behavior, that according to González (2011) is typical of fragile soil failure. In this failure, the $\Delta \sigma_{\mathrm{d}}$ increases rapidly at low strains, reaching a maximum value from which failure occurs at a well-defined point on the curve. For this w, the MC model shows an elastoplastic behavior, which represents satisfactorily the experimental stress-strain relationship except for the reproduction of the suction effect or the formation of meniscus in the soil, the maximum $\Delta \sigma_{\mathrm{d}}(3.0 \%$ of percentage error in comparison with the experimental) and the yield point. In contrast, the HS model due to its capability to represent a soft transition between the elastic and plastic region of the stress-strain curve, for this low moisture level, this model does not adjust adequately the stress-strain relationship of the soil, in comparison with the MC model. For the medium w (20\%), similar numerical results were found in comparison with 10\% (Figure 7B). For the high w (34\%) (Figure 7C), the experimental stressstrain results showed a plastic failure. Therefore, in this w value, the MC model does not adjust to the soil behavior. It is important to recall that the model used in the numerical simulations (MC) idealizes the behavior of the soil to be perfectly elastoplastic. In contrast, the HS model represented adequately the stress-strain relationship for this w, with a percentage error of $4.8 \%$ of the maximum $\Delta \sigma_{\mathrm{d}}$ between the experimental and the numerical simulation result.

Table 5. Parameters used as input data in the numerical simulations for Mohr-Coulomb (MC) model for the three moisture contents.

\begin{tabular}{lccccc}
\hline $\begin{array}{l}\text { Moisture } \\
\text { content (w) }\end{array}$ & $\begin{array}{c}\text { Young's } \\
\text { modulus (E) }\end{array}$ & Poisson's ratio (v) & Cohesion $(\mathrm{c})$ & Friction angle $(\phi)$ & $\begin{array}{c}\text { Dilatancy angle } \\
(\psi)\end{array}$ \\
\hline$\%$ & $\mathrm{MPa}$ & & $\mathrm{MPa}$ & $\circ$ & $\circ$ \\
10 & 24.17 & 0.33 & 0.200 & 29.0 & 0 \\
20 & 11.04 & 0.33 & 0.150 & 14.0 & 0 \\
34 & 7.38 & 0.33 & 0.058 & 2.8 & 0 \\
\hline
\end{tabular}

Table 6. Parameters utilized as input data in the numerical simulations for Hardening Soil (HS) model for three moisture contents $(\mathbf{w})$.

\begin{tabular}{|c|c|c|c|c|c|c|c|c|c|c|c|}
\hline $\mathrm{w}$ & $\phi$ & $\mathrm{c}$ & $\Psi$ & $\mathrm{E}^{\mathrm{ref}}{ }_{50}$ & $\mathrm{E}^{\text {ref }}$ oed & $\mathrm{E}^{\mathrm{ref}}$ ur & $\mathrm{m}$ & $\mathrm{v}_{\mathrm{ur}}$ & $\mathrm{p}^{\text {ref }}$ & $\mathrm{K}_{0}$ & $\mathrm{R}_{\mathrm{f}}$ \\
\hline$\%$ & o & $\mathrm{MPa}$ & o & - & $\mathrm{MPa}$ & 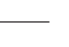 & & & $\mathrm{MPa}$ & & \\
\hline 10 & 29.0 & 0.200 & 0 & 80 & 44.950 & 160 & 1 & 0.2 & 0.100 & 0.51 & 0.9 \\
\hline 20 & 14.0 & 0.150 & 0 & 20 & 56.850 & 130 & 1 & 0.2 & 0.100 & 0.75 & 0.9 \\
\hline 34 & 2.8 & 0.058 & 0 & 24 & 45.700 & 50 & 1 & 0.2 & 0.100 & 0.95 & 0.9 \\
\hline
\end{tabular}

$\phi$ : Friction angle, c: cohesion, $\psi$ : dilatancy angle, $\mathrm{E}^{\text {ref }}{ }_{50}$ : reference secant stiffness, $\mathrm{E}^{\text {ref }}$ oed: reference tangent stiffness, $\mathrm{E}^{\text {ref }}$ ur: reference unloadingreloading stiffness, $\mathrm{m}$ : power exponent of stiffness-stress level correlation, $\mathrm{v}_{\mathrm{ur}}$ : unloading-reloading Poisson's ratio, $\mathrm{p}^{\text {ref: }}$ : reference stiffness stress, $\mathrm{K}_{0}$ : side pressure coefficient and $\mathrm{R}_{\mathrm{f}}$ : failure ratio. 
Figure 7. Comparison of numerical and experimental results of the stress-strain relationships at a $0.15 \mathrm{MPa}$ confining pressure $\left(\sigma_{3}=\sigma_{c}\right)$ for moisture content (w) of: (A) $10 \%$, (B) $20 \%$ and $(C) 34 \%$.
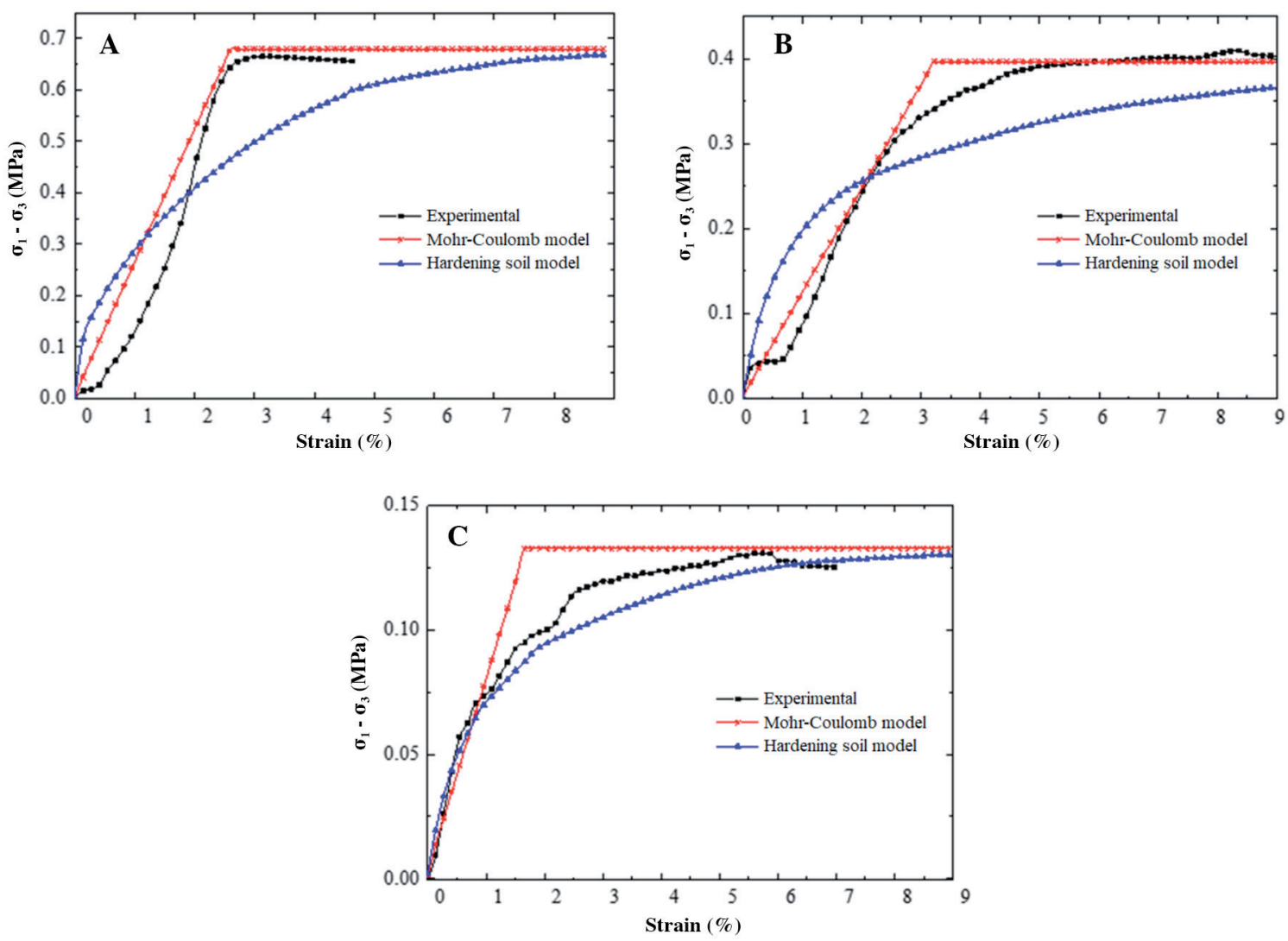

\section{CONCLUSIONS}

The experimental results revealed that an increase of water content (w) from $10 \%$ to $34 \%$, decreased significantly Young's modulus (E) and friction angle $(\phi)$, while the confining pressure values used in this work did not affect $\mathrm{E}$; also, cohesion (c) increased to a maximum when w increased from low to mid-levels, once it began saturation from mid to high $\mathrm{w}$ levels, capillary softening occurred, and the c decreased considerably. The finite element model allowed to numerically reproduce the experimental test results, by using Mohr-Coulomb (MC) and Hardening Soil (HS) material models, where MC fitted adequately for $\mathrm{w}$ between $10 \%$ and $20 \%$, while HS exhibited a better approximation for $\mathrm{w}=34 \%$.

\section{ACKNOWLEDGEMENT}

The authors are thankful to the Soil Mechanics Laboratory of the University of Guanajuato for the facilities and technical support provided during the development of this study. The first author is very grateful to the National Council of Science and Technology of Mexico (CONACYT) for the support through the scholarships granted.

\section{REFERENCES}

ASTM. 2017. ASTM D2487-17e1, standard practice for classification of soils for engineering purposes (Unified Soil Classification System). ASTM International, West Conshohocken, Pennsylvania, USA.

Bentley. 2020. PLAXIS - Material models manual. Bentley Systems, Exton, Pennsylvania, USA.

David, T., Krishnamoorthy, R.R., and Jais, M. 2015. Finite element modelling of soil-structure interaction. Jurnal Teknologi 76(8):59-63. doi:10.11113/jt.v76.5625. 
Duan, K., Kwok, C.Y., and Ma, X. 2017. DEM simulations of sandstone under true triaxial compressive tests. Acta Geotechnica 12(3):495-510. doi:10.1007/s11440-016-0480-6.

Dunbabin, V.M., Postma, J.A., Schnepf, A., Pagès, L., Javaux, M., Wu, L., et al. 2013. Modelling root-soil interactions using threedimensional models of root growth, architecture and function. Plant and Soil 372(1-2):93-124. doi:10.1007/s11104-013-1769-y.

González, O. 2011. Modelación de la compactación provocada por el tráfico de neumáticos, de los vehículos agrícolas, en suelos en condiciones de laboratorio. 62 p. PhD thesis. Universidad Agraria de La Habana, Centro de Mecanización Agropecuaria, San José de las Lajas, Cuba.

Herrera, M., Coronel, C., González, O., y Bravo, E. 2008a. Simulación mediante el Método de Elementos Finitos de la respuesta mecánica de un Oxisol. Revista Ciencias Técnicas Agropecuarias 17(2):55-61.

Herrera, M., González, O., Iglesias, C., de La Rosa, A., y Andino, R. 2010. Estudio de la exactitud del modelo hiperbólico de Duncan y Chan en la predicción de la relación esfuerzo deformación de tres suelos arcillosos cubanos. Revista Ciencias Técnicas Agropecuarias 19(4):24-29.

Hossne, A., Paredes, G., Carvajal, R., Santaella, E., y Malaver, J. 2011 . Cohesión aparente de un suelo agrícola franco arenoso de sabana. Acta Universitaria. 21(3):5-13. doi:10.15174/au.2011.15.

Huang, C., Wang, X., Zhou, H., and Qin, D. 2020. Dynamic elastic modulus and damping ratio of unsaturated red clay. Geotechnical and Geological Engineering 38(1):873-881 . doi:10.1007/s10706-019-01117-3.

Jawad, A.A., Almuhanna, R.R., and Shaban. A.M. 2020. Three-dimensional finite element analysis for determining subgrade reaction modulus of subgrade soils. IOP Conference Series: Materials Science and Engineering 745(1):012137. doi:10.1088/1757-899X/745/1/012137.

Leal, J., Gallegos, G., and Rojas, E. 2012. The Decrease of the strength of unsaturated silty sand. Ingeniería Investigación y Tecnología 13(4):393-402.

Lee, S.J., Hashash, Y.M.A., and Nezami, E.G. 2012. Simulation of triaxial compression tests with polyhedral discrete elements. Computers and Geotechnics 43:92-100. doi:10.1016/j.compgeo.2012.02.011.

Leong, E.C., Nyunt, T.T., and Rahardjo, H. 2013. Triaxial testing of unsaturated soils. Springer Series in Geomechanics and Geoengineering 3:33-44. doi:10.1007/978-3-642-32492-5_3.

Mánica, M.A., Gens, A., Vaunat, J., and Ruiz, D.F. 2018. Nonlocal plasticity modelling of strain localisation in stiff clays. Computers and Geotechnics 103:138-150. doi:10.1016/j.compgeo.2018.07.008.

Mendoza, C., Farias, M., y da Cunha, R.P. 2014. Validación de modelos constitutivos avanzados de comportamiento mecánico para la arcilla estructurada de Brasilia. Obras y Proyectos (15):52-70. doi:10.4067/s0718-28132014000100005.

Nguyen, H.B.K., Rahman, M.M., and Fourie, A.B. 2018. Characteristic behavior of drained and undrained triaxial compression tests: DEM study. Journal of Geotechnical and Geoenvironmental Engineering 144(9):1-13. doi:10.1061/(ASCE)GT.1943-5606.0001940.

Nieto Leal,A., Camacho Tauta, J., y Ruiz Blanco, E. 2009. Determinación de parámetros para los modelos elastoplásticos mohr-coulomb y hardening soil en suelos arcillosos. Revista Ingenierías Universidad de Medellín 8(15):75-91. https://revistas.udem.edu.co/index.php/ingenierias/article/view/63.

Ren, F., He, J., Zhang, F., Wang, G., and Zhao, Q. 2018. Numerical investigation of the influence of non-uniform factors on the monotonic/cyclic behaviour of coarse-grained soil. Computers and Geotechnics 103:115-137.

SEMARNAT. 2000. NOM-021-SEMARNAT-2000, que establece las especificaciones de fertilidad, salinidad y clasificación de suelos - estudios, muestreo y análisis. Diario Oficial de la Federación (DOF), México. Secretaría de Medio Ambiente y Recursos Naturales (SEMARNAT), Ciudad de México, México.

Teo, P.L., and Wong, K.S. 2012. Application of the Hardening Soil model in deep excavation analysis. IES Journal Part A: Civil and Structural Engineering 5(3):152-165. doi:10.1080/19373260.2012.696445.

Torres Guerrero, C.A., Gutiérrez Castorena, M.C., Alberto, C., Ortiz Solorio, C.A., y Gutiérrez Castorena, E.V. 2016. Manejo agronómico de los Vertisoles en México: una revisión. Terra Latinoamericana 34(4):457-466.

Tracy, S., Black, C., Roberts, J., and Mooney, S. 2011. Soil compaction: A review of past and present techniques for investigating effects on root growth, Journal of the Science of Food and Agriculture 91(9):1528-1537. doi:10.1002/jsfa.4424.

Ucgul, M., Saunders, C., and Fielke, J.M. 2018. Comparison of the discrete element and finite element methods to model the interaction of soil and tool cutting edge. Biosystems Engineering 169:199-208. doi:10.1016/j.biosystemseng.2018.03.003.

Ungureanu, N., Vladut, V., and Biris, S.S. 2017. FEM modelling of soil behaviour under compressive loads. IOP Conference Series: Materials Science and Engineering 163(1):012001. doi:10.1088/1757-899X/163/1/012001.

Wu, J.T.H., and Tung, S.C.Y. 2020. Determination of model parameters for the Hardening Soil Model. Transportation Infrastructure Geotechnology 7(1):55-68. doi:10.1007/s40515-019-00085-8.

Zhao, C.L., and Zang, M.Y. 2017. Application of the FEM/DEM and alternately moving road method to the simulation of tiresand interactions. Journal of Terramechanics 72:27-38. doi:10.1016/j.jterra.2017.04.001. 